\title{
Margaret McCartney: Nurses must be allowed to exercise professional judgment
}

\author{
Margaret McCartney general practitioner
}

Glasgow

As doctors hand over more clinical decisions and responsibility to other healthcare professionals, they need to know that their colleagues can exercise their own professional judgment. A recent decision by the nursing regulator suggests that, for nurses at least, considerable challenges remain.

The Nursing and Midwifery Council (NMC) investigated a complaint brought by a nursing home against one of its staff members. The nurse had "failed to attempt cardiopulmonary resuscitation (CPR)" and "failed to contact or ensure that the emergency services were contacted."

One of the council's panels heard that a resident was discovered "waxy, yellow and almost cold." No "do not resuscitate" order was in place. The facts of what happened otherwise are not included in the public judgment. ${ }^{1}$ But paramedics later attended, the police found no evidence of suspicious behaviour, and the coroner determined death from natural causes.

The judgment is extraordinary. A caution order was given, to last for 24 months; the panel found that the nursing profession had been brought into disrepute, that the nurse's fitness to practise was impaired, and that patients had been at risk of harm.

The nurse was not represented at the hearing by herself, her union, or a defence body. She submitted reflective essays demonstrating remorse and acceptance that she had been in error. The panel noted that she had "undertaken re-training to address the deficiencies in her practice and to update her knowledge. Specifically, she has undertaken a course in 'end of life care' and 'death, dying, and bereavement."'

Experienced nurses are no longer able to exercise rational, compassionate, professional judgment: their regulator excoriates them when they do

The NMC has prioritised blame over evidence, again. ${ }^{2}$ A useful investigation should have asked why a patient at high risk of death had not had a "do not resuscitate" form completed. This isn't just the responsibility of an individual nurse but a responsibility shared with the nursing home management, primary care providers, and, more broadly, the NHS.
The council says that nurses "must deliver care based on the best available evidence or best practice." Yet guidance written by the BMA, the Resuscitation Council, and the Royal College of Midwives states that "there will be cases where healthcare professionals discover patients with features of irreversible death ... In such circumstances, any healthcare professional who makes a carefully considered decision not to start CPR should be supported by their senior colleagues, employers and professional bodies."

If we want professional protection, the obvious answer is to do CPR on everyone if there's a margin of doubt that a "do not resuscitate" order exists. But this would cause deaths to be unnecessarily medicalised and bodies to be brutalised after death, without hope of benefit to the patient.

The judgment on the investigation into Janet Tracey's death highlighted the concerns of the Resuscitation Council, which noted that the number of inappropriate CPR attempts had been falling and that "a judgment requiring consultation with the patient save in exceptional cases would be likely to reverse that process." This has now come to pass.

It seems that experienced nurses are no longer able to exercise rational, compassionate, professional judgment, for their regulator excoriates them when they do.

Competing interests: See www.bmj.com/about-bmj/freelancecontributors/margaret-mccartney.

Provenance and peer review: Commissioned; not externally peer reviewed.

Follow Margaret on Twitter, @mgtmccartney

bmj.com Personal View: My mum's care means that decisions not to resuscitate must now be discussed with patients (BMJ 2017;356:j1084, doi:10.1136/bmj.j1084)

Nursing and Midwifery Council. Conduct and Competence Committee substantive hearing 9 Jan 2017. https://www.nmc.org.uk/globalassets/sitedocuments/ttpoutcomes/2017/ january-2017/reasons-kendall-cccsh-048388-20170109.pdf.

2 Nursing and Midwifery Council. Conduct and Competence Committee substantive hearing-consensual panel determination. 3 Mar 2017. https://www.nmc.org.uk/ globalassets/sitedocuments/ttpoutcomes/2017/march-2017/reasons-dearden-cccsh52583-20170303.pdf 
3 BMA, Resuscitation Council (UK), Royal College of Nursing. Decisions relating to cardiopulmonary resuscitation (3rd ed). Oct 2014. https://www.resus.org.uk/dnacpr/ decisions-relating-to-cpr/.

4 Royal Courts of Justice. Tracey $v$ Cambridge University Hospitals NHS Foundation Trust and others. 17 Jun 2014. https://www.judiciary.gov.uk/wp-content/uploads/2014/06/traceyapproved.pdf.
Published by the BMJ Publishing Group Limited. For permission to use (where not already granted under a licence) please go to http://group.bmj.com/group/rights-licensing/ permissions 